\title{
Formation of a Financial Security Management Mechanism Based on the Introduction of New Information Technologies
}

\author{
Anzhela P. Lelechenko ${ }^{1, *}$, Vladyslava V. Iyzefovych ${ }^{1}$, Iryna I. Doronina ${ }^{2}$, Tykhon S. Yarovoi ${ }^{3}$, \\ Viktoriia V. Tomakh ${ }^{4}$ \\ ${ }^{1}$ Department of Regional Governance, Local Self-Government and Urban Management, National Academy for Public Administration \\ under the President of Ukraine, 03057, Kyiv, Ukraine \\ ${ }^{2}$ Department of Economic Policy and Governance, National Academy for Public Administration under the President of Ukraine, 03057, \\ Kyiv, Ukraine \\ ${ }^{3}$ Department of Public Administration, Interregional Academy of Personnel Management, 03039, Kyiv, Ukraine \\ ${ }^{4}$ Department of Management, Logistics and Innovations, Simon Kuznets Kharkiv National University of Economics, 61166, Kharkiv, \\ Ukraine
}

Received March 23, 2021; Revised May 30, 2021; Accepted June 15, 2021

\section{Cite This Paper in the following Citation Styles}

(a): [1] Anzhela P. Lelechenko, Vladyslava V. Iyzefovych, Iryna I. Doronina, Tykhon S. Yarovoi, Viktoriia V. Tomakh, "Formation of a Financial Security Management Mechanism Based on the Introduction of New Information Technologies," Universal Journal of Accounting and Finance, Vol. 9, No. 3, pp. 487 - 497, 2021. DOI: 10.13189/ujaf.2021.090323.

(b): Anzhela P. Lelechenko, Vladyslava V. Iyzefovych, Iryna I. Doronina, Tykhon S. Yarovoi, Viktoriia V. Tomakh (2021). Formation of a Financial Security Management Mechanism Based on the Introduction of New Information Technologies. Universal Journal of Accounting and Finance, 9(3), 487 - 497. DOI: 10.13189/ujaf.2021.090323.

Copyright $\mathrm{C} 2021$ by authors, all rights reserved. Authors agree that this article remains permanently open access under the terms of the Creative Commons Attribution License 4.0 International License

\begin{abstract}
The article is devoted to the current problem of forming a strategy-oriented mechanism for managing the financial security of Ukrainian enterprises based on the introduction of new information technologies. It was established that transformational processes in the economy of Ukraine create the need to search for modern and effective ways to ensure the sustainable development of economic entities. The approaches to the definition of the financial security category of the enterprise are generalized and provided the author's definition of this category taking into account the strategically oriented approach. The main strategic guidelines are systematized, which are a prerequisite for the formation of an effective and efficient mechanism for managing the financial security of a modern enterprise of Ukraine in the context of the information and digital economy. A financial security management mechanism has been established to solve the problem of ensuring financial security, assess the level of financial security. A set of measures aimed at using the available resources and capabilities of the enterprise are taken. Proposals are presented for solving typical tasks on
\end{abstract}

information and analytical support of the management process of financial security of the enterprise by means of introduction of new information technologies.

Keywords Economic Security, Strategy, Information Technologies, Analytical Subsystem, Destabilizing Factors

\section{Introduction}

Financial security is one of the important components of economic security of the enterprise, along with other components, such as personnel, technical and technological, intellectual, energy, environmental, information.

One of the main conditions for successful growth and operation of the enterprise is the formation of an effective system of financial and economic security. In the era of global digitalization, companies effectively manage financial security with the latest technology, which minimizes economic cyberattacks. Today the financial 
system of Ukraine is at the beginning of its formation and only acquires the features inherent in the market economy of developed countries. As noted by A. A. Khomenko, the processes of disorganization and criminalization of this system create preconditions for a significant threat to financial security of the country as a whole business entity [1]. It also negatively impact the development of the banking system of Ukraine, which operates in unpredictable economic and financial conditions, which leads to unstable, inefficient in terms of financial performance and poor performance of banks and enterprises in various industries and spheres of production and service [2]. It should also be noted that now the situation at Ukrainian enterprises is often very difficult they use outdated and uncompetitive (especially in the foreign market) equipment, land issues are not resolved, large accounts payable and receivable are accumulated, and seasonal production often exists. All this determines the relevance of finding ways and mechanisms to ensure sustainable development of these enterprises, the effectiveness of financial security management, and the creation of a modern and reliable system of financial security for the business entity using new information technologies.

The purpose of this article is to study the formation of a strategically oriented mechanism of financial security management, based on the introduction of new information technologies by Ukrainian enterprises.

The problem of forming a mechanism for managing the financial security of enterprises through the involvement of new information technologies has attracted the attention of a large number of domestic scientists, namely: A. Khomenko [1], K. Orekhov [2], N. E Avanesova, T. V. Momot, O. S. Mordovtsev and Y. I. Sergienko [3; 4], O. A. Kirichenko, V. S. Sidak and S. M. Laptiev [5], A. S. Ostapenko and T. M. Povod [6], V. V. Zimovets [7], Yu. Romanenko [8], O.A. Diegtyar, A. P. Lelechko and N. S. Orlova [9; 10], A. Yu. Gevorgyan [11], K. S. Fen [12], A. A. Tkachuk [13]. Their works are devoted to the problems of research and formation of a universal and effective strategy-oriented mechanism for managing the financial security of Ukrainian enterprises. Despite the significant interest of Ukrainian scholars and practitioners in the formation of the mechanism of financial support, it should be noted that existing research is mainly devoted to various aspects of determining the nature of category and, and the problems of introducing new information technologies in economic security management remain unresolved.

To achieve the goal of the study, the following goals are identified:

- to generalize approaches to the interpretation of the category "financial security of the enterprise" and make the definition of this category a specific author; - to systematize strategic guidelines for ensuring the financial security of the enterprise;
- to create a universal mechanism for financial security management, based on the introduction of new information technologies by Ukrainian enterprises;

- to develop an information-analytical subsystem for managing the financial security of the enterprise within the existing mechanism;

- give proposals to solve typical tasks of information and analytical support of the process of financial security management of the enterprise through the introduction of new information technologies.

\section{Literature Review}

Today there is an urgent need for effective management and control of the level of economic security of enterprises in a timely manner to identify existing risks and prevent possible threats through the use of modern information technology developments. It provides for the development of universal and effective mechanisms to ensure the appropriate level of a key component of economic security, namely financial security. In 1985, Committee of Sponsoring Organizations (COSO) of the Treadway Commission was established, which developed a common model of internal control [14] by which companies and organizations, including banks, can evaluate their own management systems. This model is used by the whole world. The COSO model defines the internal control of an organization as a process carried out by the board of directors, senior management and other personnel of the organization, designed to provide "reasonable confidence" in achieving goals in the following categories: efficiency and effectiveness, the reliability of financial reporting and compliance with laws and regulations. The essence of the COSO model can be expressed as follows: you manage when risk is assessed and managed. Ukrainian enterprises cannot use this model without taking into account regional peculiarities, the distinctiveness of Ukraine legislation from EU and the economic situation of the country, so there is a need for theoretical and methodological substantiation.

It should also be borne in mind that the direct management of financial security should be considered as an integral part of the overall mechanism of enterprise management, the main focus of which is to combat internal and external threats to its operation and development. Therefore, to increase the theoretical and methodological significance of our study, it is useful to separate the category of "financial security" from the concept of "economic security" and give it an author's definition.

The category "economic security of the enterprise" can be defined as the "ability of the enterprise to develop and effectively perform financial and economic operations in ever-changing internal and external conditions, which is the state of protection of its important interests by internal and external destabilizing factors in the present and progress in the future" [3] 
It should be noted that destabilizing factors (challenges, risks, threats, hazards) mean a combination of existing and potential phenomena and factors that create a danger to the realization of the interests of the enterprise in the economic direction of its development.

E. L. Oleynikov represented this term as follows: "the economic security of an enterprise is the state of the most efficient use of corporate resources to prevent threats and to ensure stable operation of the enterprise now and in the future" [15].

Malamedov gives the following definition: "by economic security of an entrepreneurial structure we mean the protection of its vital interests from internal and external threats, that is, the protection of the entrepreneurial structure, its human and intellectual potential, information, technology, capital and profit, which is ensured by a system of measures special legal, economic, organizational, information-technical and social nature" [16].

Economic security is a state of stability in which an enterprise can carry out business activities, while it maintains equilibrium in a changing external and internal environment, in conditions of destabilizing factors. The key parameters of the economic security of the organization is financial independence, financial stability, stability, the ability to develop, update funds, and improve the market [17].

Considering approaches to the definition of "financial security of the enterprise" in more detail, T. V. Momot and N. E. Avanesova noted that the financial security of the enterprise is a component of the economic security based on the independence and efficiency of the enterprise. It is reflected through a system of criteria and indicators of its financial conditions, characterizing the balance of finances, sufficient liquidity of assets and the availability of necessary reserves. It is characterized by the balance and quality of financial instruments, technologies, services, resilience to internal and extremal threats, and the ability to ensure the realization of own financial interests, missions, and tasks with sufficient financial resources. This is reflected through a system of criteria and indicators of its financial condition, characterizing the balance of finances, sufficient liquidity of assets, and the availability of necessary reserves [4].

O. A. Kyrychenko, V. S. Sidak and S. M. Laptiev under the definition "financial security of the enterprise" mean that the state should protect the financial interests of enterprises from threats, ensure the stable protection of financial interests from identified real and potential threats of external and internal character, and create the necessary prerequisites for financial support for its sustainable growth in the current and future periods [5].

According to A. S. Ostapenko and T. M. Povod, financial security management is the ability to carry out its activities efficiently and consistently. The ability of the business entity to carry out its financial activities efficiently and sustainably through the use of a combination of interrelated diagnostic, instrumental and control measures of a financial nature, which should optimize the use of financial resources, ensure their appropriate level and mitigate the impact of risks [6].

Some scientists [7] consider this category as the ability of the enterprise to develop and implement a financial strategy in accordance with the objectives of a corporate strategy, in an uncertain and competitive environment based on the developed financial plan and forecasts.

Instead, other researchers [18] believe that the financial security of the enterprise is an activity to manage risk and protect the interests of the enterprise from external and internal threats in order to ensure the stable development of entrepreneurship and the growth of its equity in the current and strategic prospects. The ability of the enterprise to identify and reveal risks, the introduction of modern methods for managing them, and the development of measures to eliminate them, neutralize or smooth out the consequences are the main tasks.

A. I. Mokii and O. I. Datsko regard the economic essence of financial security as a system that ensures the stability of important financial proportions of development. A balanced state of its elements and subsystems as a separate economic system, which can be expressed by quantitative indicators and is characterized by resistance to negative effects of the external and internal environment, able to ensure its effective functioning, the stability of development, and economic growth [19].

The authors of "Approaches to assessing the interaction of financial security of economic entities and financial security of the state" interpret this term as follows: "Specific type of economic relationship that arises between the enterprise and the entities of its external environment to ensure the optimal financial condition in which the enterprise must be located to implement its strategy and which is characterized by the ability of the enterprise to withstand external and internal threats" [20].

Among the studies of foreign scientists, what is crucial is the approach of G. Shinazi, who defines financial security of enterprises as "the ability to promote and expand business processes of the corporation, manage risks of activities and level their consequences". So, based on this interpretation, the category of financial security is characterized by a feature of continuity in time: it can be modified only as a derivative set of all elements of the category of "finances" [21].

\section{Materials and Methods}

Today, there is an urgent need for effective management and control of the level of economic security of enterprises to timely identify existing risks and prevent possible threats based on the use of modern developments of information technology. It provides for the 
development of universal and effective mechanisms to ensure the appropriate level of the key component of economic security, namely, financial security. It should also be taken into account that direct financial security management should be considered an integral part of the overall enterprise management mechanism, the main focus of which is to counter internal and external threats to its functioning and development. Therefore, to increase the theoretical and methodological value of our study, it is useful to separate the category of "financial security" from the concept of "economic security" and provide it with an author's definition.

As for the definition of the "enterprise economic security" category, it can be defined as "the ability of an enterprise to develop and perform financial and economic operations effectively in an ever-changing internal and external environment, that is, the state of protection of its important interests from internal and external destabilizing factors to ensure stability in the present and progression in the future" [3]. It should be noted that destabilizing factors (challenges, risks, threats, hazards) mean a combination of existing and potential phenomena and factors that are dangers to the realization of the interests of the enterprise in the economic direction of its development. Approaches to the definition of "financial security of the enterprise" (Figure 1) should be considered in more detail.

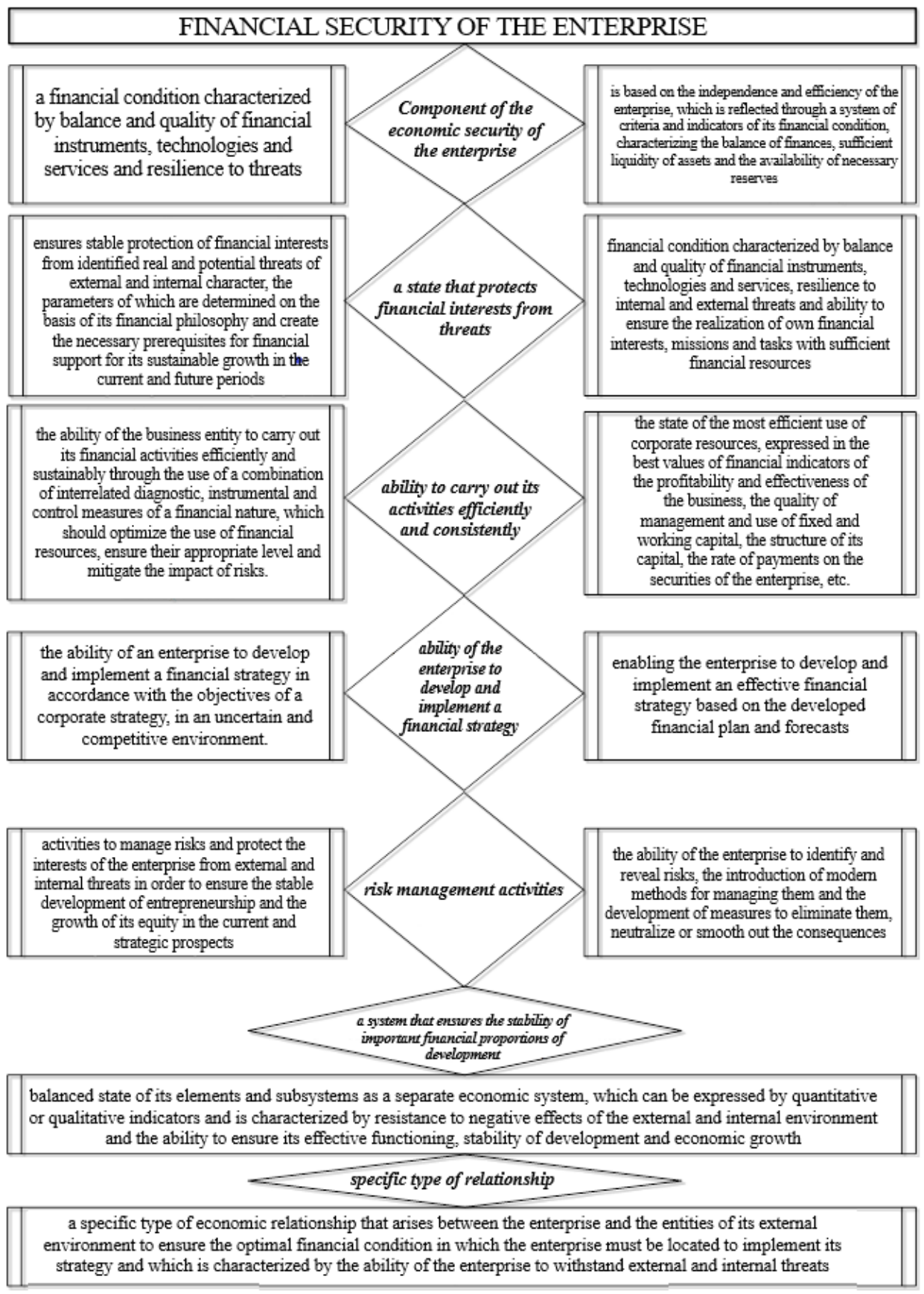

Figure 1. Approaches to defining the financial security category of the enterprise 


\section{Results and Discussion}

As a result of the study of approaches to the definition of the category "financial security of the enterprise", a generalized author's definition of this category can be made. So, the "financial security of an enterprise" in the article will be understood as a key component of economic security, which is an integrated process of management actions and decisions aimed at achieving the desired or expected financial condition, dependent on the priority financial interests of the enterprise, the key activity of which is the identification of challenges and the neutralization of risks, threats and hazards arising from the introduction and the implementation of financial policies and strategies based on the introduction of modern information technologies.

Based on the above definition, it can be concluded that the strategic management of the financial security of enterprises is a system of consistent management decisions to select and implement strategic alternatives that should ensure the sustainable development, protection, and balance of the financial interests of the enterprise while having an effective risk management mechanism and avoid destabilizing threats to the internal and especially external environment to achieve the strategic goals of the enterprise.

At the same time, it is impossible to reliably assess the state of economic security of the enterprise, without taking into account the economic processes and phenomena that occur in Ukraine and directly affect the level and components of economic security. Therefore, it is appropriate to identify three groups of factors influencing the process of assessing the level of economic security of the enterprise in terms of European integration:

1. European integration factors of the macro level, covering the peculiarities of Ukraine's location in the central part of Europe.

2. European integration factors at the meso level, by which we mean the factors influencing the company.

3. European integration factors of the micro level, covering the economic activity of companies [22;23].

The main strategic guidelines that are a prerequisite for the formation of an effective mechanism for managing the financial security of a modern enterprise in Ukraine in the context of the information and digital economy are:

- The formation of a system of financial interests that should be protected in the course of the enterprise

- The identification of challenges, analysis of internal and extremal threats and forecasting risks of financial security of the enterprises that can potentially or actually lead to risks

- Implement effective mechanism to respond to challenges, manage financial risks, and address or neutralize threats to the financial security of the enterprise
- The development of integrated financial security practices

- The assessment of the financial security of the enterprise with new information technologies

- The development of a plan for implementation of the established set of measures based on the creation of the financial security management mechanism of the enterprise

- The analysis of strategic results achieved after implementation of proposed actions

- The introduction of new information technology to improve financial security management

Continuous operational management of the introduction and implementation of strategic guidelines for the financial security of the enterprise by establishing a feedback mechanism to adjust existing or prospective measures to ensure the expected and/or desired level of financial security [8-10;24].

It can be concluded that all the strategic guidelines shown by the enterprise should be based on the development and implementation of a systematic financial security management mechanism using continuous monitoring and new information technologies.

This mechanism should include clusters of theoretical and methodological frameworks to solve the problem of ensuring the financial security, financial security assessments, and a set of measures aimed at using existing resources and capabilities of the enterprise to protect its financial interests from challenges, threats, risks and hazards to achieve stable and effective functioning and set goals and objectives for the strategic development of enterprises (Figure 2).

In the last year, the Ukrainian economy has been experiencing significant inflationary processes caused by the coronavirus SARS-CoV-2, which affect both the welfare of Ukrainian citizens and the efficiency of enterprises. In addition, the absence financial resources leads to the inability of the financial system to provide the state with financial resources sufficient to perform its internal and external functions, which in general poses a threat to national security. Significant threats to Ukraine's financial security lie in the sphere external debt, the significant dependence of enterprises on the exchange rate of the national currency, the growth of the shadow sector of the economy, and, accordingly, the negative balance of payments balance.

Therefore, there is an urgent issue of creating not only the management of financial security of economic entities, but also the national security of the state as a whole. Here are some statistics to obtain a more complete picture of the difficult situation both in the country and for enterprises, which confirms the deterioration of their financial security.

According to the Ministry of Economic Development and Trade Ukraine, the total volume of industrial output in January-February 2019 , compared to the same period in 
2018, decreased by $4.2 \%$ [25]. According to the State Statistics Service of Ukraine, the index of industrial production in January 2020, compared to January 2019, was $78.7 \%$ [26]. The volume index of agricultural production in January 2020, compared to January 2019, was $97.6 \%$ [26]. The physical volume of wholesale trade in January-February 2019, compared to that in the same period in 2018 , decreased by $2.5 \%$ [26]. The industrial producer price index (PPI) in January 2020 was $102.3 \%$. Nominal GDP for 2018 amounted to UAH 1,454.9 billion [26]. Ukraine's real GDP in 2018 compared to 2016 (at constant 2018 prices) was $100.0 \%$. GDP per capita in 2018 amounted to UAH 31,984 , which is $0.2 \%$ more than in 2016. In February 2019, the producer price index of industrial products amounted to $99.8 \%$, from the beginning of $2019-100.3 \%$. In February 2019, the consumer price index amounted to $100.6 \%$, from the beginning of $2019-100.8 \%$ [26]. In January-February 2019 , cash outside banks increased by $6.4 \%$, money supply - by $2.8 \%$, the monetary base - by $0.4 \%$. The level of monetization of the national economy at the end of February 2019 was $55.7 \%$. The share of cash in circulation in the structure of the money supply at the end of February 2019 was $27.1 \%$ against $26.2 \%$ at the end of 2018 , in the structure of the monetary base $-82.1 \%$ against $77.4 \%$ at the end of 2018 [25].

Debts on loans granted to the economy of Ukraine since the beginning of 2019 increased by $7.2 \%$ and amounted to UAH 976.1 billion at the end of February 2019 [25]. The amount of loans granted in national currency, decreased by $1.8 \%$, in foreign currency - increased by $24.8 \%$. Banks' liabilities on attracted deposits increased by $1.4 \%$ from the beginning of 2019 and amounted to UAH 679 billion at the end of February 2019. From the beginning of the year, the volume of attracted deposits in the national currency decreased by $7.0 \%$, in the foreign currency - increased by $15.5 \%$. Liabilities on deposits with household accounts increased by $1.6 \%$ to UAH 449 billion [25]. NBU from 06.02.2020 increased the discount rate from $14 \%$ to $19.5 \%$, and from 04.03 .2020 - up to $30 \%$ [27].

Thus, with a decrease in the financial and economic condition of enterprises (one of the indicators of which is the index of industrial production), the threat to financial security of the state increases (in particular, the ratio of public and state-guaranteed debt to GDP), and vice versa. 


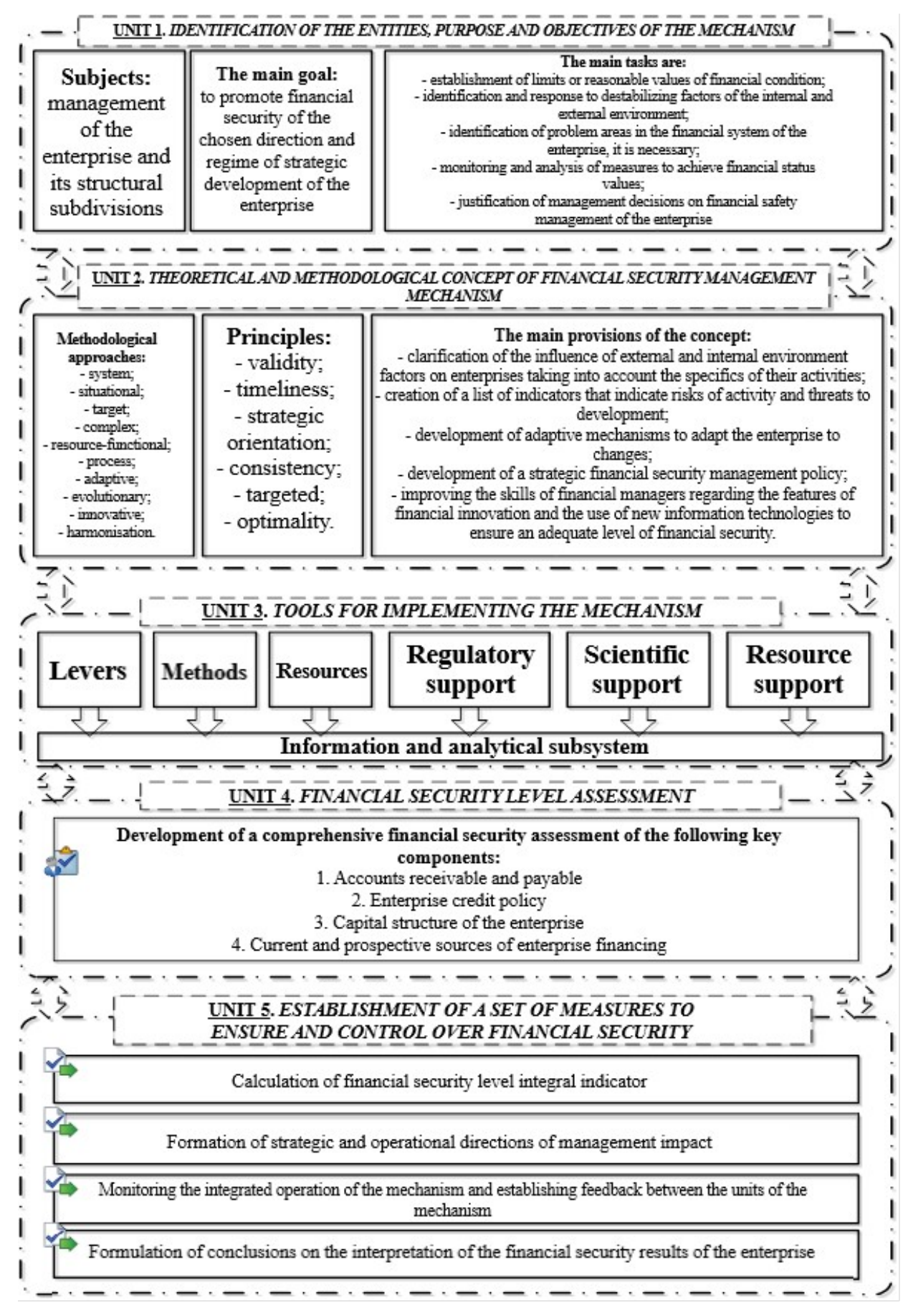

Sourse: Complied by authors based on $[11-13 ; 28]$

Figure 2. Financial security management mechanism based on the introduction of new information technologies by Ukrainian enterprises

As can be seen from Figure 2, in the financial security management mechanism of the enterprise, the information and analytical subsystem is of great importance, which is a set of information sources, economic parameters, including the chosen methodology for assessing and analyzing the level of financial security of the enterprise [29]. It was noted that modern business conditions require continuous monitoring of potential risks, collection of reliable, up-to-date, and high-quality information with its subsequent processing. The effectiveness of decisions made by financial managers depends precisely on the information sources that they own, manage and use to ensure financial security. It should be noted that information support should have a systemic approach in the integrated system of management of financial security of the enterprise, that is, the subsystem of information and analytical support in the management of financial security of the enterprise should interact with all elements of the enterprise management system. Collected and processed information flows play a key role at the beginning of the 
development of the financial security strategy of the enterprise.

Thus, the information and analytical subsystem of financial security management of the enterprise can be defined as an integrated process consisting of some tools aimed at collecting information sources, their assessment, and analysis, forecasting the obtained results of conducting activities [30]. In turn, heads of the enterprise and its structural subdivisions should clearly design the tasks of the information and analytical subsystem and the ways of its implementation into the financial security system. Therefore, it is useful to make a diagram of the information and analytical subsystem of financial security management of the enterprise in Figure 3.

So, at the exit of the information and analytical subsystem of financial security management of Figure 4, the enterprise should receive high-quality information to ensure the effective operation of the mechanism developed in Figure 3, which will be used in the future to assess the level of financial security and develop a set of financial and managerial control measures for the implementation of priority areas and guidelines of the selected strategy. It should also be noted that the important place of the developed subsystem (Figure 4) is the introduction of new information technologies - this, in turn, means a radical change in the outdated methods of obtaining, processing, interpreting, and transmitting information to the management of the enterprise. We propose solutions of typical tasks on information and analytical support of the process of management of financial security of the enterprise using the introduction of new information technologies in Table 1.

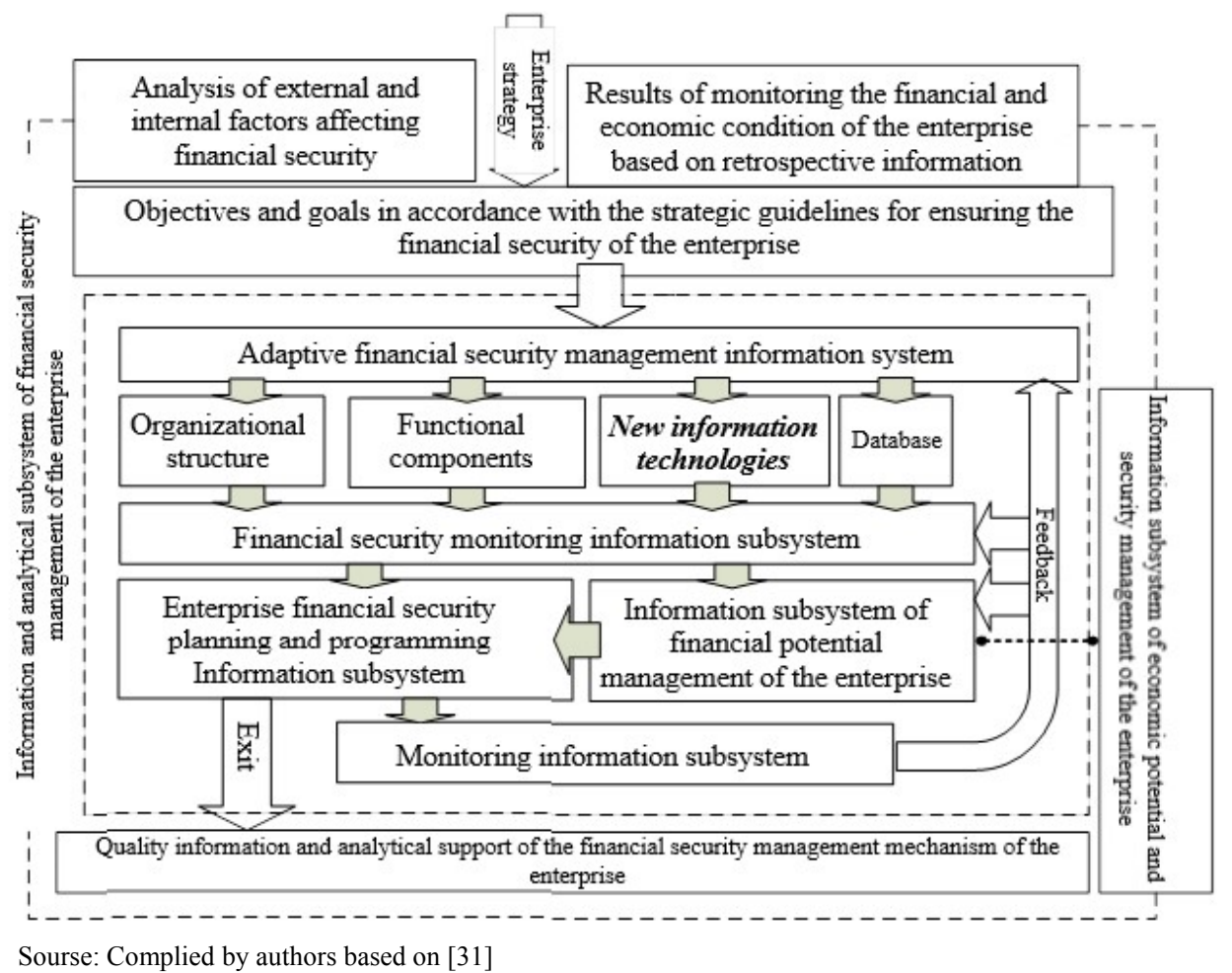

Figure 3. Information and analytical subsystem of financial security management of the enterprise [20] 
Table 1. Introduction of new information technologies in the process of financial security management

\begin{tabular}{|c|c|c|}
\hline No. & $\begin{array}{l}\text { The problem area of information and analytical } \\
\text { support }\end{array}$ & Solving the problem with new information technology \\
\hline 1 & $\begin{array}{l}\text { Information about the emergence of destabilizing } \\
\text { financial security factors appears at one time in only } \\
\text { one place, which often does not allow a timely } \\
\text { adequate response to it }\end{array}$ & $\begin{array}{l}\text { Through the creation and implementation of distributed databases, } \\
\text { information on destabilizing factors will appear simultaneously in } \\
\text { different places, which will accelerate the reaction and development of a } \\
\text { set of measures to neutralize or reduce their destructive impact. }\end{array}$ \\
\hline 2 & $\begin{array}{l}\text { Only experts can develop and implement financial } \\
\text { security measures in the enterprise, which is usually an } \\
\text { inefficient and resource-intensive process }\end{array}$ & $\begin{array}{l}\text { The company can use one of the existing grant programs for the } \\
\text { development of small and medium enterprises (SMEs) in Ukraine, } \\
\text { thereby minimizing the cost of financial support measures. In general, } \\
\text { the introduction of expert systems will facilitate the process of managing } \\
\text { the financial security of the enterprise, so the work of a financial security } \\
\text { expert can be performed by a specialist in general financial and } \\
\text { economic issues. When implementing expert systems, it is necessary to } \\
\text { take into account the characteristics of each enterprise, depending on } \\
\text { which expert systems, how to develop them and how to implement them. }\end{array}$ \\
\hline 3 & $\begin{array}{l}\text { The continuous search for an optimal management } \\
\text { model (centralized or decentralized) can weaken the } \\
\text { financial security of the enterprise }\end{array}$ & $\begin{array}{l}\text { Modern telecommunications models will allow the using of the } \\
\text { advantages of the positive features of both the centralized management } \\
\text { model and the capabilities and aspects of decentralized management. An } \\
\text { enterprise can create with the help of the Ministry of Digital } \\
\text { Transformation of Ukraine (using the online platform "Diya. Business") } \\
\text { a reliable system of financial security based peculiar on the enterprise. }\end{array}$ \\
\hline 4 & $\begin{array}{l}\text { Management decisions to ensure financial security are } \\
\text { made by managers without the active participation of } \\
\text { enterprise personnel, which makes it impossible to } \\
\text { stimulate both financial security and the professional } \\
\text { growth of individual employees }\end{array}$ & $\begin{array}{l}\text { To solve this problem, the following technologies should be introduced: } \\
\text { decision support tools, access to the database, modeling tools. This will } \\
\text { make management decisions part of the work of each staff member, } \\
\text { which will positively affect the functioning of the common financial } \\
\text { security system }\end{array}$ \\
\hline 5 & $\begin{array}{l}\text { Current force majeure conditions due to quarantine } \\
\text { measures often make it impossible for financial } \\
\text { security specialists to be in the workplace, which } \\
\text { makes it difficult for them to receive, store and transfer } \\
\text { relevant information }\end{array}$ & $\begin{array}{l}\text { The development and implementation of a corporate enterprise } \\
\text { information management system with remote access to the necessary } \\
\text { information and the ability to perform the necessary functions will allow } \\
\text { financial security specialists to fulfill their tasks and obtain the desired } \\
\text { results. }\end{array}$ \\
\hline 6 & $\begin{array}{l}\text { The process of planning for the financial security of } \\
\text { enterprises is carried out periodically, and therefore } \\
\text { plans may not correspond to operational situational } \\
\text { needs for the protection of financial interests of } \\
\text { enterprises }\end{array}$ & $\begin{array}{l}\text { The creation of a financial security department and specialized } \\
\text { high-performance software that allows you to view plans in real time and } \\
\text { adjust them to the current situation will help protect the financial } \\
\text { interests of enterprises. }\end{array}$ \\
\hline
\end{tabular}

As a result of the introduction and implementation of new information technologies in the activities of enterprises, the financial security management mechanism will be optimized and the following results will be obtained [32-35]:

- the problem of inconsistency between the objectives of the various structural divisions of the enterprise has been solved;

- it is possible for a financial security specialist to be intersectional and perform more tasks;

- giving autonomy in decision-making by individual specialists and selecting options to achieve the overall goal of strengthening the financial security of the enterprise;

- the company personnel is being trained in the economic and financial security of the enterprise;

- changing the functions of managers and senior managers - they consist not only of issuing managing and controlling influences, but also with the help of team members in solving problems of strengthening financial security;

- the orientation of the enterprise to process control (current process approach), and not to individual functions; the ability to address a large number of levels of financial security management adequately when there is an "excess" allocation of liabilities;

- prerequisites are created for continuous strategic and operational planning, the adjustment of basic and specific indicators that directly and indirectly affect the financial security of the enterprise, as well as for the introduction of innovations into this process.

\section{Conclusion}

The studies were conducted on the formation of a strategically oriented financial security management mechanism based on the introduction of new information technologies by Ukrainian enterprises and the following theoretical, methodological and practical conclusions and results were obtained in the article. Approaches to the interpretation of the category "financial security of an enterprise" are summarized and it is concluded that a universal definition of this concept can be considered: it is a key component of economic security, which is a comprehensive process of management actions and decisions aimed at achieving the desired or expected 
financial condition, dependent on the priority financial interests of the enterprise, the key area of which is the identification of challenges and the neutralization of risks, threats and hazards arising from the introduction and implementation of financial policy and existing strategy based on the introduction of modern information technologies.

Strategic guidelines for ensuring the financial security of the enterprise were systematized and established. They are prerequisites for the formation of an effective and efficient mechanism for managing the financial security of a modern enterprise of Ukraine in the context of the information and digital economy. A universal mechanism for financial security management has been formed based on the introduction of new information technologies by enterprises of Ukraine, which should give units of theoretical and methodological basis to solve the problem of ensuring financial security, assess the level of financial security. A set of measures are taken, aiming at using the available resources and capabilities of the enterprise to protect its financial interests from challenges, threats, risks and hazards in order to achieve stable and effective functioning and set goals and objectives of strategic development of enterprises.

An information and analytical subsystem of financial security management was developed within the framework of the existing mechanism, at the exit of which the enterprise should receive high-quality information to ensure the effective operation of the mechanism, which will be used in the future to assess the level of financial security and develop a set of financial and managerial control measures for the implementation of priority areas and guidelines of the selected strategy. It has been proved that the main feature of the developed financial security management subsystem is the introduction of new information technologies, which, in turn, should radically change the outdated methods of obtaining, processing, interpreting and transmitting information to the management of the enterprise. Proposals for solving standard tasks for information and analytical support of the process of management of financial security of the enterprise through introduction of new information technologies are presented and possible advantages and positive trends as a result of successful implementation of this process are analyzed.

The scientific novelty of the results is that it helps improve the methodological approach to assessing the level of economic security of companies, which, in contrast to existing ones, takes into account the impact of European integration factors and unstable market environment that allows it possible to determine the level of economic security, which require management decisions. In addition, proposals for optimizing the process of assessing the level of economic security of enterprises have been developed, which, in contrast to the existing ones, allow it possible to form a set of recommendations taking into account the economic conditions of the enterprise. Areas for the implementation of these recommendations may be the subject of further research. The results of the study can be used by Ukrainian enterprises in the process of ensuring the required level of their economic security.

\section{REFERENCES}

[1] A. Khomenko. Mechanism of forming of financial safety of enterprises of agroindustrial complex, Baltic Journal of Economic Studies, Vol. 2, No. 2, 184-188, 2016.

[2] K. Orekhova. The process for forming a financial security strategy of an enterprise, Financial and Credit Activity: Problems and Theories and Practices, Vol. 2, No. 17, 158-172, 2014

[3] N. E. Avanesova, O. S. Mordovtsev, Yu. I. Serhiienko. Theoretical-methodical principles of identification and interrelation of the influence of destabilizing factors on the economic security of an industrial enterprise, Business Inform, Vol. 9, 20-28, 2020.

[4] T. V. Momot, N. E. Avanesova. Economic Security of Entrepreneurship of the Defense-Industrial Complex of Ukraine: Theory, Methodology, Practice, Kharkiv National University of Municipal Economy named after O. M. Beketov, Kharkiv, 2018.

[5] O. A. Kyrychenko, V. S. Sidak, S. M. Laptiev. Problems of Economic Security Management of Economic Entities, UEP "Krok", Kyiv, 2018.

[6] A. S. Ostapenko, T. M. Povod. Logistic approach to managing financial flows of business, Market Infrastructure, Vol. 25, 746-751, 2018.

[7] V. V. Zymovets, A. I. Danylenko, O. O. Tereshchenko. Financial Support of Structural Modernization of the Real Sector of the Economy of Ukraine, National Academy of Sciences of Ukraine, Kyiv, 2017.

[8] Y. Romanenko. Place and role of communication in public policy, Actual Problems of Economics, Vol. 176, No. 2, 25-31, 2016.

[9] A. P. Lelechenko, O. A. Diegtiar, O. Y. Lebedinska, T. M. Derun, O. V. Berdanova. Mechanisms of inter-state communications for solving sustainable development problems, Asia Life Sciences Supplement, Vol. 29, No. 2, $1-9,2020$.

[10] O. A. Diegtiar, N. S. Orlova, O. V. Kozureva, A. M. Shapovalova, S. I. Prykazka. Financial capacity of territorial communities: european experience and Ukrainian case, Collection of Scientific Works "Financial and Credit Activity: Problems of Theory and Practice", Vol. 4, No. 31, 516-526, 2019.

[11] A. Yu. Gevorkyan, O. S. Druhova, S. V. Klepikova. Factors influencing the determination of investment attractiveness and business value, Bulletin of the National Technical University "Kharkiv Polytechnic Institute", Vol. 19, No. 1295, 131-134, 2018. 
[12] K. S. Fen. Economic security management system of food industry enterprises. Formation of market relations in Ukraine, Bulletin of the Kyiv National Economic University named after Vadym Hetman, Vol. 4, No. 203, 115-119, 2018.

[13] H. O. Tkachuk, V. V. Zeleniak, H. M. Pavlenko, A. V. Tkachuk. The Mechanism of Ensuring the Functioning of Accounting and Analytical Activities in the System of Economic Security of Enterprises, Scientific and Methodological Principles of Business Evaluation in the Context of European Integration, I. S. Ivanchenko Publishing House, Odesa, 2019.

[14] J. Krstić, M. Đorđević. Internal control and enterprise risk management - from tradicional to revised COSO model, Economic themes Vol. 50, No. 2, 151-166, 2012

[15] E. L. Oleynikov. Fundamentals of Economic Security Gosudarstvo region predpriiatie lichnost [Foundations of economic security (State, region, enterprise, personality)] Moscow, Intel-Synthesis, 1997.

[16] S. L. Melamedov. Formirovanie strategii ekonomicheskoi bezopasnosti predprinimatelskikh struktur [Formation of the strategy of economic security of business structures] St. Petersburg, 2002

[17] A.O.Kalashnikov. Information risk management of organizational systems: general statement of the problem, Information and Security, Vol.19, No. 1, 36-45, 2016.

[18] Z. S. Varnalii, Z. B. Zhyvko, R. R. Bilyk, S. B. Onyshchenko, M. O. Zhyvko. Financial Security of the Enterprise: A Textbook, Liha-Pres, Lviv, 2018.

[19] A. I. Mokii, O. I. Datsko. Economic security of business in Ukraine: challenges and threats, Journal of Economic Reforms, Vol. 1, 17-24, 2017.

[20] L. H. Shemaieva, P. O. Tolok. Approaches to assessing the interaction of financial security of economic entities and financial security of the state, Scientific Bulletin of the International Humanities University, Series: Economics and Management, Vol. 23, No. 2, 4-8, 2017.

[21] J. G. Schinasi. Defining Financial Stability, IMF Working Paper Series, Vol. 04, No. 187, 1-16, 2014.

[22] G.M. Chernyak. Estimation of the level of economic security of energy enterprises in the conditions of European integration, Economic Bulletin of the National Technical University of Ukraine "Kyiv Polytechnic Institute", Vol. 12, 159-166, 2015.

[23] S. L. Melamedov. Formirovanie strategii ekonomicheskoi bezopasnosti predprinimatelskikh struktur [Formation of the strategy of economic security of business structures] St.
Petersburg, 2002.

[24] O. M. Nepomnyashchyy, O. A. Marusheva, Yu. H. Prav, O. V. Medvedchuk, I. A. Lahunova. Certain aspects of the system of public administration of universities: World practices and the Ukrainian dimension, Universal Journal of Educational Research, Vol. 8, No. 11D, 82-86, 2020.

[25] The main indicators of economic and social development of Ukraine, Ministry of Economic Development and Trade of Ukraine, Online available from me.kmu.gov.ua.

[26] Industry, State Statistics Service of Ukraine, Online available from www.ukrstat.gov.ua.

[27] Discount rate of the National Bank of Ukraine, National Bank of Ukraine, Online available from www.bank.gov.ua.

[28] E. Lyppol, G. Ermolenko. A fuzzy-plural approach to assessing the economic security of enterprises in Ukraine's energy-generating industry, Management of Modern Socio-Economic Systems, Vol. 2, 1-18, 2017.

[29] Ya. Hidetoshi, G. Masatoshi, Ya. Yoshinori, "Short-Termism, Excessive Executive Compensation, and the Discounting Traits of Managers - by Using fMRI Experiment," Universal Journal of Accounting and Finance, Vol. 8, No. 1, pp. 1 - 20, 2020. DOI: 10.13189/ujaf.2020.080101.

[30] H. O. Tkachuk. Technologies of the system of economic security of the enterprise: A scientific approach to application, Scientific View: Economics and Management, Vol. 1, No. 67, 112-116, 2020.

[31] I. O. Bashynska. Innovative information technologies to ensure the intellectual and personnel component of economic security of enterprises, Innovative Economics: Theoretical and Practical Aspects, Vol. 1, No. 23, 607-635, 2016.

[32] J. Kaczmarek. The mechanisms of creating value vs. financial security of going concern-sustainable management, Sustainability (Switzerland), Vol. 11, No. 8, Article number: 2278, 2019.

[33] O. Sylkin, M. Kryshtanovych, A. Zachepa, S. Bilous, A. Krasko. Modeling the process of applying anti-crisis management in the system of ensuring financial security of the enterprise, Business: Theory and Practice, Vol. 20, 446-455, 2019.

[34] N. Zachosova, O. Herasymenko, A. Shevchenko. Risks and possibilities of the effect of financial inclusion on managing the financial security at the macro level, Investment Management and Financial Innovations, Vol. 15, No. 4, 304-319, 2018. 